\title{
9. Constitutional litigation and the Commonwealth $^{1}$
}

\section{David Bennett AC QC}

As a rule, Australians tend to be ignorant, perhaps blissfully so, of the existence, terms and effect of the Constitution of the Commonwealth of Australia. A 1987 survey indicated that only about half of the population was aware that Australian had a written constitution. ${ }^{2}$ A 1994 survey of people aged fifteen years or over indicated that only 13 per cent felt that they knew something about what the constitution covered and only 18 per cent actually showed some degree of understanding of what the constitution covered. ${ }^{3}$

Of course, participants in, and keen observers of, Australian politics would be well aware of the potential impacts of the courts' decisions in constitutional cases. An obvious example of a case that has attracted considerable attention in this community is the High Court's decision in the Work Choices case. This decision has stimulated vigorous debate on the future of the federal arrangement provided for by the constitution. However, the manner by which the disputes that give rise to these decisions are conducted in the courts is, perhaps, not well understood by many politicians and political scientists, let alone lawyers. Potentially, the topic is both very broad and very technical. However, I will confine myself to outlining the manner by which the Commonwealth participates in, and thus influences the outcome of, constitutional cases before the courts. When I refer to 'the Commonwealth' I refer, in a general sense, to the Australian Government. Specifically, my essay will address the following questions:

- How do constitutional cases come before the courts?

- How does the Commonwealth become aware of constitutional cases?

- By what power is the Commonwealth able to participate in constitutional cases?

- How does the Commonwealth participate in constitutional cases?

- What are the advantages of the way the Commonwealth participates in constitutional cases?

\section{How do constitutional cases come before the courts?}

A court does not express its view on a question of law unless it has jurisdiction in relation to a dispute between parties. And, by the word 'dispute', I do not mean a dispute merely concerning what the law is - for example, a dispute over what is the proper interpretation of a particular provision of the constitution. Generally speaking, for a federal court to have jurisdiction in relation to a dispute 
between parties relating to a constitutional issue it is necessary, at least, that there be a 'matter' - that is, 'some immediate right, duty or liability to be established by the determination of the Court' ${ }^{4}$ Thus, a constitutional dispute must be real, not merely hypothetical or academic, before the courts will consider it.

As some provisions in the constitution tend to be more productive of disputes about the existence of relevant rights, duties or liabilities than others, the courts have had the opportunity to consider and express their views on some provisions in the constitution more than others. It is important to note that constitutional litigation does not always, or even generally, arise between polities - that is, the Commonwealth, the states and territories - or their officers, and so on. Constitutional litigation may arise as a result of a disputed right, duty or liability affecting only natural persons or corporations. There are many examples of such cases. One example is Smith vs ANL Ltd ([2000] 204 CLR 493), which concerned an employee who argued that he was entitled to assert his common law right to sue his employer for damages for personal injury sustained during his employment, despite the existence of a Commonwealth act that appeared to bar him from doing so. The employee argued that the act was invalid to the extent that it had the effect of acquiring the employee's existing right of action without providing just terms contrary to s.51(xxxi) of the constitution. The employer argued that the act did not infringe s.51(xxxi). The High Court agreed with the employee. The Commonwealth was not initially a party to the proceeding, as it was not involved in any way on the facts. However, the Attorney-General did intervene in the case in order to argue in support of the validity of the Commonwealth act. (I discuss what is meant by the concept of 'intervention' below.)

Another, more recent, example is Australian Pipeline Ltd vs Alinta ([2007] 159 FCR 301), which concerned a provision of the Corporations Act 2001 that allowed the Takeovers Panel to make a declaration that 'unacceptable circumstances' existed in relation to the affairs of a company in relation to a proposed takeover bid. Having made a declaration of unacceptable circumstances, the panel could then make various orders in relation to the circumstances. Failure to comply with the orders was a criminal offence, and the panel could apply to the court to seek to enforce its orders. The dispute arose between companies involved in the proposed takeover. Again, the Commonwealth was not initially involved; however, the Attorney-General intervened in order to argue in support of the validity of the provision. The Full Court of the Federal Court held that the relevant provision was invalid, on the basis that it purported to confer judicial power on an administrative body. The judgment was then appealed to the High Court, which came to the opposite view. 


\section{How does the Commonwealth become aware of constitutional cases?}

Obviously, where the Commonwealth is a party to a case that involves a dispute about the meaning or application of a provision of the constitution then it is aware of that fact. The more interesting question is how the Commonwealth becomes aware of constitutional cases to which it is not (originally) a party.

The effect of s.78B of the Judiciary Act 1903 is that, whenever a proceeding in a federal or state court raises a constitutional question, the court hearing the matter cannot proceed unless it is satisfied that a notice of this fact has been provided to the attorneys-general of the Commonwealth, the states, the Northern Territory and the Australian Capital Territory. The purpose of the provision is to give the attorneys-general the opportunity to 'intervene' in the proceeding or to apply to the High Court to have the proceeding removed into the High Court under s.40(1) of the same act. Incidentally, s.78B contains a trap for young players seeking to comply with it. It requires the notices be given to the attorneys-general of 'the states'. The Act defines 'states' for this purpose as including the Australian Capital Territory and the Northern Territory.

\section{By what power does the Commonwealth participate in constitutional cases?}

Obviously, where the Commonwealth has initiated a proceeding that involves a constitutional issue, or where it is a defendant or respondent in such a proceeding, it is able to participate in the proceeding. Again, the more interesting question is: by what power does the Commonwealth participate in other constitutional cases?

Section 78A of the Judiciary Act confers on the Attorney-General of the Commonwealth the power to 'intervene' in a proceeding before a court if the proceeding raises a constitutional question. As an intervener, the Attorney-General is taken to be a party to the proceeding, with the effect that the Attorney-General is able to address arguments to the court in relation to that question, even though the Commonwealth's rights, duties and liabilities might not be directly affected by the outcome of the case. As an intervenor, the Attorney-General is also able to appeal from a judgment given in the proceeding.

There are a number of factors that can influence the Attorney-General's decision whether to intervene in a constitutional case, including:

- whether the matter involves an attack on the validity of a Commonwealth law (as was the case in Smith vs ANL and Australian Pipeline Ltd vs Alinta, the cases referred to above, where the Attorney-General intervened) 
- whether the constitutional principles involved are well established by decisions of the High Court, or are the subject of a reserved judgment of the High Court

- the level of the court (that is, lower court or superior court, single judge or appellate court)

- whether there is likely to be an appeal from the judgment of the court

- whether a Commonwealth party is already involved in the matter

- whether the applicant is represented, and whether the applicant's constitutional argument is well conceived.

\section{How does the Commonwealth participate in constitutional cases?}

If the case is one to which the Commonwealth is not a party, the first step is for the Attorney-General to decide whether to intervene. Generally, s.78B notices are received in the Attorney-General's office, which forwards the notice to the Constitutional Litigation Unit of the Australian Government Solicitor (AGS). AGS is a law firm owned by the Commonwealth. Pursuant to the Legal Services Directions 2005 (which are made under the Judiciary Act), generally speaking, and subject to my role as the Solicitor-General, constitutional work can be performed only by AGS and the Attorney-General's Department.

AGS forms a view on whether the Attorney-General should intervene. In doing so, AGS consults with the Solicitor-General, the Constitutional Policy Unit of the Attorney-General's Department and any other area of the department or other department that has a policy interest in the subject matter of the notice (for example, if the constitutional issue is the validity of a Commonwealth law, AGS consults with the department that administers that law). If AGS and the Solicitor-General agree that there should be no intervention, the Attorney-General is not further consulted and there is no intervention.

If the Attorney-General approves intervention, generally, AGS acts for the Attorney-General in the conduct of the matter, but briefs counsel to appear for the Attorney-General at the hearing. Generally, AGS will brief one senior and one junior barrister. The pool of talent from which counsel are selected includes the Solicitor-General, senior constitutional lawyers employed by AGS (for example, AGS's Chief General Counsel, Henry Burmester) and private barristers with expertise in constitutional law. Generally, where the matter is of significant importance to the Commonwealth, or where the matter is particularly complex, AGS will brief the Solicitor-General to appear, along with a junior barrister. The Attorney-General has issued guidelines on briefing the Solicitor-General. 


\section{What are the advantages of the way the Commonwealth participates in constitutional cases?}

In my view, the way that the Commonwealth handles constitutional litigation allows it to present its arguments to the court in a way that ideally combines the experience and expertise of the public sector as well as private practice.

AGS and the Attorney-General's Department employ outstanding constitutional lawyers, many of whom have careers advising, and acting for, the Commonwealth in relation to constitutional matters. This deep well of experience and expertise is obviously invaluable to the Commonwealth in the conduct of its cases. AGS and Attorney-General's Department lawyers and advisers generally have strong relationships with, and the trust of, the government. These lawyers have finely honed skills in constitutional law and policy, as well as long memories of cases won and lost in the past and a good sense of some of the reasons why.

However, by also involving private counsel, the Commonwealth is able to draw on the particular skills and attributes of the private bar.

Whereas the public sector brings the advantages of specialist expertise in public law, private barristers bring specialist expertise in advocacy. Advocacy is as much a specialisation as constitutional law; a person who does something all the time will tend to do it better than someone who does it only occasionally.

Second, private barristers offer the attribute of independence. As sole practitioners bound by the cab-rank rule to act for all who come to them regardless of their personal views, private barristers tend to practice on both sides of the record. That is, leading private barristers in Australia with expertise in constitutional law will have acted for the Commonwealth and its emanations, the states and territories and their respective emanations, corporations, citizens and others over the course of their careers at the bar. They will have argued for and against the validity of Commonwealth legislation. A barrister who represents all sides over time is better able to advise his or her client at any particular time; he or she tends to have a broader view of the law than a solicitor who acts only for or against the Commonwealth.

Third, by retaining private barristers to appear for it, the Commonwealth enhances its capacity sensibly to cooperate with opponents in the conduct and, occasionally, settlement of cases. Almost universally, private barristers with expertise in constitutional law trust one another. These barristers represent a small pool of lawyers who regularly appear with, and against, each other. These circumstances facilitate a highly respectful and cordial professional culture that is amenable to the smooth conduct of litigation.

In many respects, the Solicitor-General (who, incidentally, is neither a solicitor nor a general!) tends to have a combination of these various skills and attributes. The Solicitor-General is a statutory office-holder, appointed by the 
Governor-General for a term (see the Law Officers Act 1964). The functions of the Solicitor-General are: a) to act as counsel for the Commonwealth and its emanations, and so on; b) to advise the Attorney-General on questions of law referred to him by the Attorney-General; and c) to carry out such other functions ordinarily performed by counsel as the Attorney-General requests. As a matter of practice, the dominant function of the Solicitor-General has been to appear on behalf of the Commonwealth in important constitutional cases.

Thus, like AGS and Attorney-General's Department lawyers, the Solicitor-General tends to possess the skills that arise from appearing in the area of constitutional law over time. However, the Solicitor-General has generally been selected from the pool of private barristers with expertise in constitutional law. Thus, the Solicitor-General also tends to bring with him (so far, the eight solicitors-general since Federation have all been male) the skills developed over a long career as a specialist advocate at the bar, representing many interests over that career and forging many strong relationships with fellow barristers. Finally, there is an advantage in the Solicitor-General appearing in almost all the major constitutional cases because of the importance of the Commonwealth not putting submissions in one case that are inconsistent with its submissions in another and the desirability of not giving an answer to a question from the Bench in one case that might be used against the Commonwealth in another. This is not a problem when one appears for a private litigant.

\section{Conclusion}

I have attempted to demonstrate that the ways in which the Commonwealth conducts constitutional litigation enable it to combine the best aspects of constitutional legal experience in the public sector with the specialist skills and knowledge of the private bar. Hopefully, from this mix of expertise, we are better able to advance the public interest.

\section{ENDNOTES}

1 This essay was originally presented as an ANZSOG Public Lecture on 16 July 2008.

2 Final Report of the Constitutional Commission. Volume One, 1988, p. 43.

3 ANOP Research Services Pty Ltd (1994), referred to in Patapan, Haig 1994, 'The forgotten founding: civics education, the common law and liberal constitutionalism in Australia', Griffith Law Review, vol. 14, no. 1, p. 91.

4 The Advisory Opinions case (1921) 29 CLR 257. 